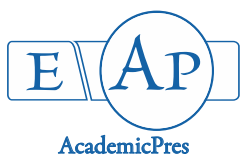

Omeke JN et al. (2021)

Notulae Scientia Biologicae

Volume 13, Issue 4, Article number 10727

DOI: $10.15835 / \mathrm{nsb} 13410727$

Research Article

\title{
Haemato-biochemical alterations and acute toxicity study of hydro- methanol root extract of Anacardium occidentale in cockerels
}

\author{
Jacinta N. OMEKE ${ }^{1}$, Onyinyechukwu A. AGINA ${ }^{1 *}$, John I. IHEDIOHA ${ }^{1}$ \\ Aruh O. ANAGA ${ }^{2}$, Wilfred S. EZEMA ${ }^{1}$, John O.A. OKOYE ${ }^{1}$
}

\author{
${ }^{1}$ University of Nigeria, Nsukka, Faculty of Veterinary Medicine, Department of Veterinary Pathology and Microbiology, Nsukka, \\ EnuguState,Nigeria; jacinta.omeke@unn.edu.ng; onyinye.noel@unn.edu.ng (*corresponding author); john.ihedioha@unn.edu.ng; \\ wilfred.ezema@unn.edu.ng;joaokoye@yahoo.com \\ ${ }^{2}$ University of Nigeria, Nsukka, Faculty of Veterinary Medicine, Department of Veterinary Physiology, Pharmacology and \\ Biochemistry, EnuguState, Nigeria; aruh.anaga@unn.edu.ng
}

\begin{abstract}
The study evaluated the haemato-biochemical alterations and acute toxicity of hydro-methanol root extract of Anarcaduim occidentale (AO) in cockerels. Forty chickens randomly assigned into four groups (A, B, C and D) of 10 birds each were used for the experiment. Groups A, B, C and D received 3000, 1500 and 500 $\mathrm{mg} / \mathrm{kg}$ body weight of the extract and distilled water respectively. Relative weights, haematology, serum biochemistry, gross and histopathological features of the lymphoid organs of chickens were studied. No significant $(P>0.05)$ variation was observed in their body weights. The white blood cell count of group A chicken were significantly $(P<0.05)$ lower than that of groups $\mathrm{B}$ and $\mathrm{C}$ chickens. Serum biochemistry tests revealed significant $(P<0.05)$ variations at different doses for the alanine aminotransferase, alkaline phosphatase, serum total protein, albumin, cholesterol, triacylglycerol, uric acid, creatinine, calcium and phosphorus activities when compared to the control group. Gross and histopathological examinations showed no overt alterations in the tissues examined. It was observed that varied doses of root extract of Anarcaduim occidentale caused significant decrease in haematology and serum biochemistry parameters of chickens and no obvious lesions in internal organs.
\end{abstract}

Keywords: Anacardium occidentale; chickens; haematology; root extract; serum biochemistry

\section{Introduction}

Poultry production is an important component of the livestock sector worldwide. Poultry industry is now one of the emerging, promising, beneficial, and important sectors that have been contributing progressively to the global economy. In Nigeria, poultry is the most commonly kept livestock and over $70 \%$ of the farmers keep chickens (Armar-Klemesu and Maxwell, 1999). Development of the poultry sector in Nigeria is being hampered by several factors of which diseases are considered as the major factor. Enormous resources go down the drain each year due to outbreaks of diseases in poultry. Currently, there is a large and everexpanding global population base that prefers the use of natural products in preventing and treating medical problems. Consequently, many pharmaceutical companies have been influenced to produce new formulations

Received: 06 May 2020. Received in revised form: 13 Sep 2021. Accepted: 18 Oct 2021. Published online: 02 Nov 2021.

From Volume 13, Issue 1, 2021, Notulae Scientia Biologicae journal uses article numbers in place of the traditional method of continuous pagination through the volume. The journal will continue to appear quarterly, as before, with four annual numbers. 
extracted from plants and herbs (Jassim and Naji, 2003). Medicinal use of extracts of various parts of Anacardium occidentale (AO) (Cashew tree) has been reported worldwide. The AO tree has been known as multipurpose tree whose leaves, stem and bark extracts are used extensively for treatment of different diseases such as tumour, venereal diseases, congestion, cold and dental caries (Agedah et al., 2010; Arekemase et al., 2011). Our earlier study had shown that root extract of AO is safe in in-vitro and in-vivo model and therefore can be used in ethnomedicine (Omeke et al., 2018a). The plant leaf is used as an additive in poultry feed to improve growth performance and the production of quality eggs (Aroche, et al., 2019).

Clinical biochemistry together with haematology, pathological and physical examinations remain the corner stone of medical diagnosis of diseases in animals and man (Stockham, 2008). Clinical biochemistry plays a vital role in avian species, which commonly show minimal overt signs of disease even when ill (Harr, 2009; Nse Abasi et al., 2014). Quantitative determination of a wide variety of substances (substrates, enzymes and hormones) in serum helps to assess the functional status of the vital organs such as kidney and liver. Investigation of blood constituents play vital role in assessing the physiological, pathological and nutritional status of an organism; this provides opportunity to assess the presence of several metabolites and other constituents in the animal body (Stockham, 2008; Nse Abasi et al., 2014). These parameters indicate the degree of organ damage and the response of the disease to therapy (Cole, 1986; Harr, 2009). Alteration in the constituent compounds of blood when compared to normal value could serve as a reflection of the metabolic state of an animal (Wheater et al., 1987). These are thus used to evaluate the systemic relationship and physiological adaptations in the body of animal exposed to toxicant and stresses due to environmental, nutritional and pathological factors (Harr, 2009; Afolabi et al., 2010; Saulawa et al., 2012). Haematology and clinical biochemistry parameters in chickens are generally used as an aid to diagnosis of organic, infectious, noninfectious and parasitic diseases. Animals with good blood composition are likely to show good performance (Isaac et al., 2013).

Interest in medicinal plants have increased recently especially on their effects on humans. Evaluation of the safety or hazards presented by substances such as pharmaceuticals, natural products and industrial chemicals prior to use is very vital. Laboratory study and tests on blood profile are important tools that help in detecting any deviation from the normal in the animal or human body (Benjamin, 1981). A search through available literature showed that there are no reports on the safety of Anacardium occidentale and its effect on haematology and clinical biochemistry parameters use in avian species except for that of Omeke et al. (2018a); hence the present study, which evaluated alterations in haematology and clinical biochemistry of chickens given varied acute doses of Anacardium occidentale root extract.

\section{Materials and Methods}

\section{Plant collection and identification}

Fresh root of AO was sourced from Nsukka town in Nsukka Local Government Area, Enugu State of South-East Nigeria in January 2018. The samples were taken to the Department of Plant Science and Biotechnology, University of Nigeria Nsukka (UNN) for proper identification and the voucher sample (UNN|H.AO|2018.2) was kept in the herbarium of the Department.

\section{Preparation and extraction of plant materials}

The root of $\mathrm{AO}$ was sorted to remove any unwanted particles. They were chopped into small bits and dried under shade in World Bank Assisted STEP B Drug Discovery laboratory in the Department of Veterinary Physiology and Pharmacology University of Nigeria Nsukka. The dried specimens were pulverized using hammer mill in the Department of Crop science, UNN into coarse powder. The specimen was extracted using cold maceration by soaking $500 \mathrm{~g}$ in 3 liters of $70 \%$ hydro-methanol for 48 hours with intermittent shaking. The extracts were filtered using Whatman No 1 filter paper. The filtrate was concentrated to dryness using hot 
air oven (Gallenkamp) at $40{ }^{\circ} \mathrm{C}$. The crude extract was weighed to determine the percentage yield. The percentage yield was calculated using the formula below:

Percentage yield $(\% \mathrm{w} / \mathrm{w})=\frac{\text { Mass of the extract }}{\text { Mass of the starting material }} \times 100$

The harvested root extract was stored in refrigerator at $4^{\circ} \mathrm{C}$ before use. The extract was dissolved using distilled water.

Experimental animals and acute toxicity study

Forty-day old cockerels were procured from Zartech Hatchery Ibadan, Nigeria and were brooded for two weeks using standard management procedures. The birds were fed with commercial feed and water ad libitum and were vaccinated against Newcastle disease and infectious bursal disease viruses. At eight weeks of age, the birds were randomly assigned into four groups of $\mathrm{A}, \mathrm{B}, \mathrm{C}$ and $\mathrm{D}$ with each group comprising 10 birds. Five birds were weighed in each group and the average weight was used to calculate the doses. They were treated with the extract at the doses of 3000, 1500 and $500 \mathrm{mg} / \mathrm{kg}$ body weight $(\mathrm{b} / \mathrm{w})(\mathrm{OECD}, 2001)$ for group $\mathrm{A}, \mathrm{B}$ and $\mathrm{C}$ respectively through oral administration using $1 \mathrm{ml}$ syringe. The control group (Group D) received 10 $\mathrm{ml} / \mathrm{kg}$ distilled water through the same route. The birds were observed for two weeks (14 days) for signs of toxicity and mortality.

\section{Blood sample collection}

Three milliliters of blood sample were collected each from five randomly selected birds for haematology and serum biochemistry 48 hours post administration of the extract from the jugular vein into labelled sample bottles. All haematological determinations followed standard procedures and were done immediately upon collection of blood samples. One milliliter was collected in a sterile sample bottle containing $1 \mathrm{mg}$ of ethylene diamine tetra acetic acid (EDTA) anticoagulant for haematology while two milliliters were collected into plain sample bottle for serum biochemistry.

\section{Haematological determination}

The packed cell volume (PCV) was determined by the microhaematocrit method with the aid of a microcapillary tube, microhaematocrit centrifuge and reader (Hawksley, England) (Coles, 1986). The haemoglobin concentration $(\mathrm{HbC})$ was determined by the cyanomethaemoglobin method (Higgins et al., 2008). The red blood cell (RBC) count was obtained by the hemocytometer method (Schalm et al., 1975) using an improved Neubauer counting chamber (Hawksley, England) and avian RBC diluting fluid (Campbell, 1994). The total WBC count was performed by the hemocytometer method using an improved Neubauer counting chamber (Hawskley, England) and a special avian WBC diluting fluid composed of aqueous phloxine, propylene glycol and sodium carbonate (Campbell, 1994). The differential WBC count was performed following the Leishman technique (Campbell, 1994). Results for each cell type were expressed as percentage of the total WBC (Thrall and Weiser, 2002).

\section{Serum biochemistry determination}

Alanine aminotransferase (ALT), aspartate aminotransferase (AST) and alkaline phosphatase (ALP) activities were determined by standard methods using Randox test kits (Randox Laboratories, UK). The serum uric acid was determined by the modified Berthelot-Scarcy method (Fawcett and Scott, 1960); while the creatinine was determined by the modified Jaffe method (Blass et al., 1974). The serum cholesterol was determined by enzymatic colorimetric test method (Allain et al., 1974). Serum total protein was obtained by the Biuret method as described by Kohn (1995) while the albumin was determined using bromocresol green following the method of Doumas (1972). The serum calcium was determined by the o-cresolphthalein method (Kessler and Wolfman, 1964) while the serum phosphorus levels were determined by Fiske-Subba-Row method (Goodwin, 1970). 


\section{Gross and histopathological determinations}

At the end of the period of observation, three birds from each group were randomly selected and humanely sacrificed for gross and histopathological studies. The spleen, thymus and bursa of Fabricius, were thoroughly examined for gross changes and collected for histopathological examination. They were fixed in $10 \%$ buffered formalin for not less than 24 hours. Histopathological studies were carried out as described by Drury and Wallington (1976).

\section{Statistical analysis}

Data collected were subjected to analysis using SPSS version 16.0 (Chicago, USA). One-way analysis of variance followed by Duncan's multiple post hoc comparison test was applied to compare the mean haematological and serum biochemistry parameters among groups. Data generated were expressed as mean \pm standard error of mean. All tests were performed with a $P<0.05$ level of significance.

\section{Results and Discussion}

\section{Acute toxicity study}

Extraction yielded $2.8 \% \mathrm{w} / \mathrm{w}$ solid materials. After administration of the extract to birds, those in group A ( $3000 \mathrm{mg} / \mathrm{kg}$ of extract) showed transient clinical signs of dullness and gasping which lasted for an hour. The birds in other groups did not show any signs of abnormality. There was no significant $(P>0.05)$ variation in mean body weight of the birds in all the groups (Table 1).

Table 1. Relative body weight of cockerels (gram) administered varied doses of root extract of Anacardium occidentale

\begin{tabular}{|l|c|c|c|c|}
\hline & \multicolumn{4}{|c|}{ Means \pm Standard deviation } \\
\hline Weeks & Group A & Group B & Group C & Group D \\
\hline Week 0 & $470.00 \pm 44.72$ & $418.00 \pm 46.04$ & $450.00 \pm 35.36$ & $444.00 \pm 37.82$ \\
\hline Week 1 & $600.00 \pm 117.26$ & $640.00 \pm 129.42$ & $640.00 \pm 54.77$ & $560.00 \pm 114.02$ \\
\hline Week 2 & $624.00 \pm 128.96$ & $684.00 \pm 126.61$ & $750.00 \pm 145.77$ & $620.00 \pm 135.09$ \\
\hline
\end{tabular}

\section{Gross and histopathological study}

Post-mortem examination of the sacrificed birds revealed no gross lesion in the spleen, thymus, and bursa of Fabricius. Histopathological examination also showed no significant alteration in the examined organs (Figure 1A-C).

\section{Haematology and serum biochemistry}

The haematology and serum biochemistry results are shown in Tables 2 and 3 respectively. There were no significant $(P>0.05)$ variations among all the groups in their mean $\mathrm{PCV}$ value, $\mathrm{Hb}$ concentration and RBC counts (Table 2), which shows that the extract has no adverse effect on these blood parameters. The total white blood cell counts of chickens given $3000 \mathrm{mg} / \mathrm{kg}$ of the extract was significantly $(P<0.05)$ lower than that of chickens given $1500 \mathrm{mg} / \mathrm{kg}$ of the extract. The mean WBC count of chickens that received $500 \mathrm{mg} / \mathrm{kg}$ of the extract and those that received distilled water did not differ $(P>0.05)$ significantly from those of other groups. The lymphocyte counts of group A $(3000 \mathrm{mg} / \mathrm{kg}$ of extract) chickens were significantly $(P<0.05)$ lower than those of groups B $(1500 \mathrm{mg} / \mathrm{kg})$ and C $(500 \mathrm{mg} / \mathrm{kg})$. The heterophil and eosinophil counts showed no significant $(P>0.05)$ variations across the groups. The mean monocyte counts in group A $(3000 \mathrm{mg} / \mathrm{kg})$ chickens were significantly $(P<0.05)$ lower than that of group B $(1500 \mathrm{mg} / \mathrm{kg})$. The higher lymphocyte counts in groups $B$ and $C$ suggest that the dose extract at 1500 and $500 \mathrm{mg} / \mathrm{kg}$ body weight boosts lymphocyte counts and thus can be useful in treatment of diseases such as infectious bursal disease and other diseases associated 
with lymphocyte depletion (Igwe et al., 2017; Omeke et al., 2018b). Also, the significantly $(P<0.05)$ higher monocyte counts in the group given $1500 \mathrm{mg} / \mathrm{kg}$ bw implies that at this dose, the extract may be useful in the treatment and management of chronic diseases and infections due to higher bacteria where monocytes and macrophages play a major role. The anti-microbial, anti-protozoa and anti-viral activities of various parts of AO has also been reported (Omojasola and Awe, 2004; Agedah et al., 2010 and Ifesan et al., 2013).

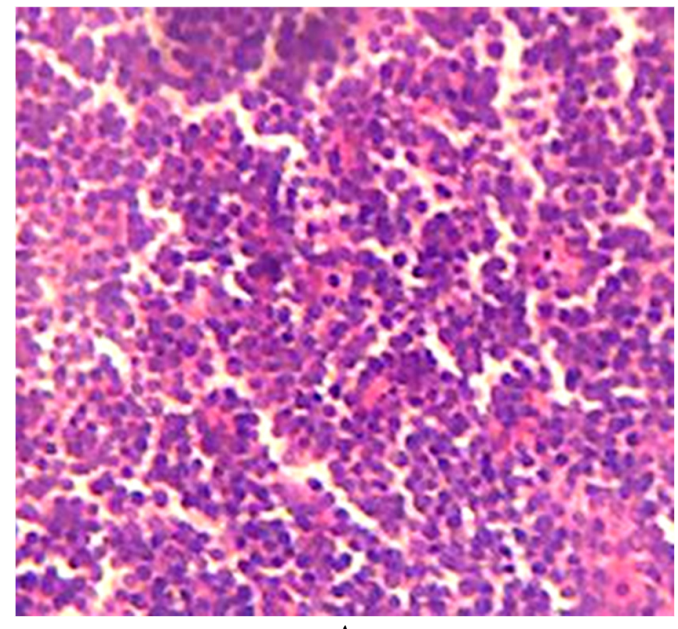

A

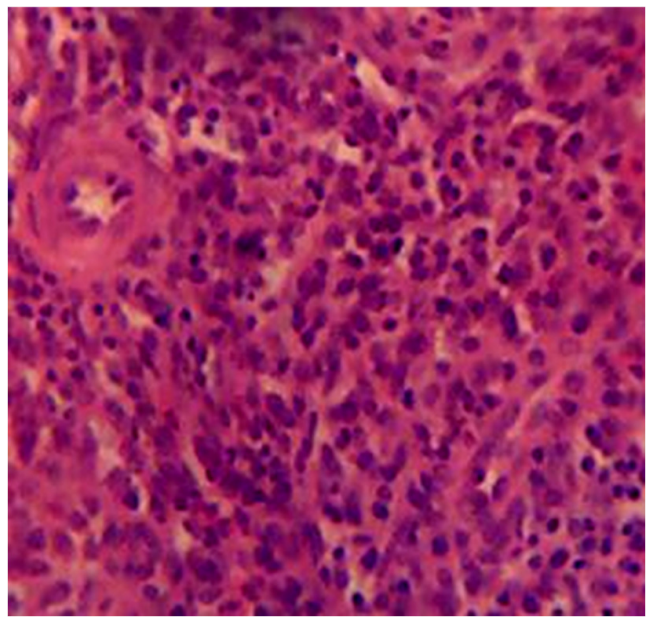

B

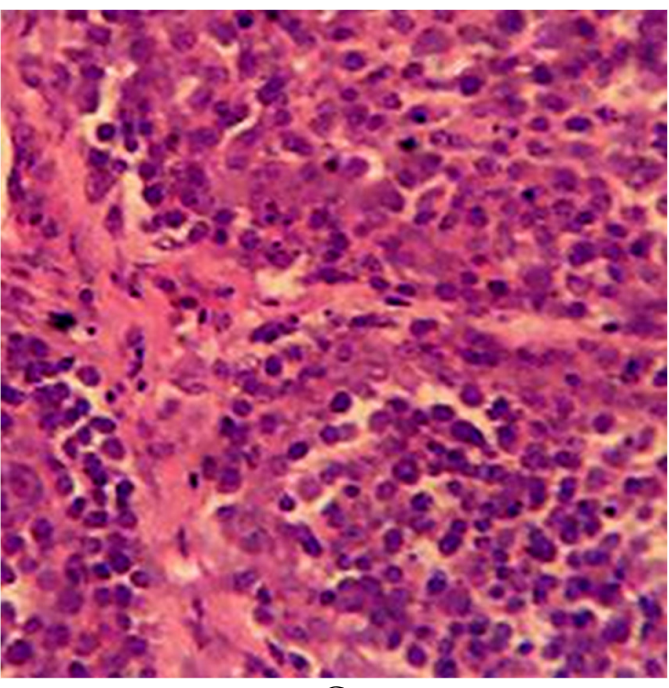

C

Figure 1. A. $\mathrm{H} \& \mathrm{E}$ thymus section from cockerels exposed to the high dose of root extract of Anacardium occidentale showing no obvious pathological change. Magnification H\&E X400; B. H \& E spleen section from cockerels exposed to the high dose of root extract of Anacardium occidentale. showing no obvious pathological change. Magnification H\&E X400; C: H \& E Bursa of Fabricius section from cockerels exposed to the high dose of root extract of Anacardium occidentale showing no obvious pathological changes with normal distribution of lymphocytes. Magnification H\&E X400 
Table 2. Haematological parameters of cockerels given varied doses of Anarcadium occidentale root extract (AORE)

\begin{tabular}{|c|c|c|c|c|}
\hline \multicolumn{5}{|c|}{ Means, with standard error in brackets } \\
\hline $\begin{array}{l}\text { Haematological } \\
\text { parameters }\end{array}$ & $\begin{array}{c}\text { Group A } \\
(3000 \mathrm{mg} / \mathrm{kg})\end{array}$ & $\begin{array}{c}\text { Group B } \\
(1500 \mathrm{mg} / \mathrm{kg})\end{array}$ & $\begin{array}{c}\text { Group C } \\
(500 \mathrm{mg} / \mathrm{kg})\end{array}$ & $\begin{array}{l}\text { Group D } \\
\text { (control) }\end{array}$ \\
\hline Packed cell volume & $\begin{array}{l}29.83 \\
(1.74)\end{array}$ & $\begin{array}{l}29.67 \\
(0.88)\end{array}$ & $\begin{array}{l}29.17 \\
(1.36)\end{array}$ & $\begin{array}{l}28.33 \\
(1.17)\end{array}$ \\
\hline $\begin{array}{l}\text { Haemoglobin conc. } \\
(\mathrm{g} / \mathrm{dl})\end{array}$ & $\begin{array}{c}8.92 \\
(1.10) \\
\end{array}$ & $\begin{array}{c}9.18 \\
(0.28) \\
\end{array}$ & $\begin{array}{c}8.75 \\
(0.56) \\
\end{array}$ & $\begin{array}{c}8.63 \\
(0.31) \\
\end{array}$ \\
\hline $\begin{array}{l}\text { Red blood cell count } \\
\left(10^{6} / \mu \mathrm{l}\right)\end{array}$ & $\begin{array}{c}3.90 \\
(0.29) \\
\end{array}$ & $\begin{array}{c}3.99 \\
(0.16) \\
\end{array}$ & $\begin{array}{c}3.85 \\
(0.33) \\
\end{array}$ & $\begin{array}{c}3.67 \\
(0.28)\end{array}$ \\
\hline $\begin{array}{l}\text { White blood cell } \\
\text { count }(/ \mu \mathrm{l})\end{array}$ & $\begin{array}{l}8367^{\mathrm{a}} \\
(4.94) \\
\end{array}$ & $\begin{array}{l}12200^{\mathrm{b}} \\
(11.64) \\
\end{array}$ & $\begin{array}{c}10433^{\mathrm{ab}} \\
(4.63) \\
\end{array}$ & $\begin{array}{l}10450^{\mathrm{ab}} \\
(12.63)\end{array}$ \\
\hline $\begin{array}{l}\text { Lymphocyte count } \\
(/ \mu \mathrm{l})\end{array}$ & $\begin{array}{l}4420^{\mathrm{a}} \\
(1.38) \\
\end{array}$ & $\begin{array}{l}7281^{\mathrm{bc}} \\
(6.47)\end{array}$ & $\begin{array}{l}6239^{c} \\
(0.48)\end{array}$ & $\begin{array}{l}5295^{\mathrm{ac}} \\
(6.81)\end{array}$ \\
\hline $\begin{array}{l}\text { Heterophil count } \\
(/ \mu \mathrm{l})\end{array}$ & $\begin{array}{l}2605 \\
(5.53)\end{array}$ & $\begin{array}{l}2135 \\
(3.14)\end{array}$ & $\begin{array}{l}2346 \\
(2.84)\end{array}$ & $\begin{array}{l}2871 \\
(3.43)\end{array}$ \\
\hline $\begin{array}{l}\text { Monocyte count } \\
(/ \mu l)\end{array}$ & $\begin{array}{c}980^{\mathrm{a}} \\
(2.52)\end{array}$ & $\begin{array}{l}2726^{\mathrm{b}} \\
(7.92)\end{array}$ & $\begin{array}{l}1471^{\mathrm{ab}} \\
(1.85)\end{array}$ & $\begin{array}{l}1795^{\mathrm{ab}} \\
(5.19)\end{array}$ \\
\hline $\begin{array}{l}\text { Eosinophil count } \\
(/ \mu \mathrm{l})\end{array}$ & $\begin{array}{c}362 \\
(0.70)\end{array}$ & $\begin{array}{c}2.02 \\
(0.79)\end{array}$ & $\begin{array}{c}377 \\
(0.52)\end{array}$ & $\begin{array}{c}0.27 \\
(0.32)\end{array}$ \\
\hline
\end{tabular}

\section{Serum biochemistry}

Results of serum biochemistry showed that there were no significant $(P>0.05)$ variations among the groups in their AST activity and globulin levels (Table 3 ). The serum ALT activity of groups A and B chickens were significantly lower $(P<0.05)$ than those in groups $\mathrm{C}$ and $\mathrm{D}$. Therefore, this suggests that the extract at the doses of 3000 and $1500 \mathrm{mg} / \mathrm{kg}$ bw may have hepatocyte membrane stabilizing effect and thus may be hepatoprotective in disorder and diseases associated with breaches in hepatocyte integrity (0zer et al., 2008; Ramaiah, 2011). Also, the ALP activity of the group B chickens was significantly $(P<0.05)$ lower than those of chickens in groups $C$ and $D$, which also implied that the membrane stabilizing effect of the $1500 \mathrm{mg} / \mathrm{kg}$ bw dose extended to the biliary epithelium which produces ALP (Ramaiah, 2011). The serum total protein and albumin levels of the group A chickens were significantly $(P<0.05)$ lower than those of groups $\mathrm{B}$ and $\mathrm{C}$ chickens, though it was not significantly $(P<0.05)$ different from that of group $\mathrm{D}$. The finding of a lower total protein and albumin levels in the group A chickens implies that treatment with $3000 \mathrm{mg} / \mathrm{kg}$ bw may have compromised the protein synthetic capability of the liver as serum total protein and albumin are synthesized by the liver (Ozer et al., 2008). The serum total cholesterol of group C that received $500 \mathrm{mg} / \mathrm{kg}$ bw of the extract had significantly lower $(P<0.05)$ serum total cholesterol value when compared to the control group. This implies that this low dose decreases total cholesterol level. The serum tricyglycerol levels of groups A, B and $\mathrm{C}$ were significantly $(P<0.05)$ lower than that of group D. The result of serum cholesterol and triacyglycerol implies that the extract exhibited a hypolipidemic effect and can thus be used to lower blood cholesterol and triacyglycerol levels and treat ailments associated with derangement in serum lipid profile (dyslipidaemia). The positive effect of AO on cholesterol level had earlier been reported by Shafe et al. (2014) and Nwozo et al. (2016).

The serum uric acid levels of groups A, B and C chicken were significantly $(P<0.05)$ lower than that of group $\mathrm{D}$, while the serum creatinine levels of groups $\mathrm{A}$ and $\mathrm{B}$ chickens were significantly $(P<0.05)$ lower than that of groups $\mathrm{C}$ and $\mathrm{D}$ (Table 3 ). The effect of this extract on uric acid and creatinine suggests that the extract improved renal function, as uric acid and creatinine are the biomarkers of kidney function (Sirois, 2015). The serum calcium of groups $\mathrm{A}$ and $\mathrm{C}$ were significantly $(P<0.05)$ lower than that of group $\mathrm{D}$, while the serum phosphorus levels of group B chickens were significantly $(P<0.05)$ lower than that of group D. The 
implications of these alterations in serum calcium and phosphorus may be that the extract can affect bone formation and egg lay as these minerals play important role in growth and reproduction (Pastore et al., 2012; Igwe et al., 2018).

Table 3. Serum biochemistry alterations in groups of cockerels given varied doses of Anarcadium occidentale root extract (AORE)

\begin{tabular}{|c|c|c|c|c|}
\hline \multicolumn{5}{|c|}{ Means, with standard error in brackets } \\
\hline $\begin{array}{c}\text { Serum Biochemistry } \\
\text { Parameters } \\
\end{array}$ & $\begin{array}{c}\text { Group A (3000 } \\
\mathrm{mg} / \mathrm{kg})\end{array}$ & $\begin{array}{c}\text { Group B } \\
(1500 \mathrm{mg} / \mathrm{kg})\end{array}$ & $\begin{array}{c}\text { Group C } \\
(500 \mathrm{mg} / \mathrm{kg})\end{array}$ & $\begin{array}{l}\text { Group D } \\
\text { (Control) }\end{array}$ \\
\hline $\begin{array}{l}\text { Aspartate } \\
\text { aminotransferase } \\
(\mathrm{U} / \mathrm{L})\end{array}$ & $\begin{array}{l}87.63 \\
(2.76)\end{array}$ & $\begin{array}{l}86.90 \\
(3.42)\end{array}$ & $\begin{array}{l}90.36 \\
(1.71)\end{array}$ & $\begin{array}{l}92.55 \\
(2.32)\end{array}$ \\
\hline $\begin{array}{l}\text { Alanine } \\
\text { aminotransferase } \\
(\mathrm{U} / \mathrm{L})\end{array}$ & $\begin{array}{l}6.34^{\mathrm{a}} \\
(0.54)\end{array}$ & $\begin{array}{l}6.93^{\mathrm{a}} \\
(0.29)\end{array}$ & $\begin{array}{l}8.84^{\mathrm{b}} \\
(0.26)\end{array}$ & $\begin{array}{l}9.72^{\mathrm{b}} \\
(0.81)\end{array}$ \\
\hline $\begin{array}{l}\text { Alkaline } \\
\text { phosphatase (U/L) }\end{array}$ & $\begin{array}{c}535.22^{\mathrm{ac}} \\
(2.86) \\
\end{array}$ & $\begin{array}{c}533.28^{a} \\
(2.07) \\
\end{array}$ & $\begin{array}{c}548.57^{b} \\
(1.39) \\
\end{array}$ & $\begin{array}{c}539.67^{\mathrm{c}} \\
(1.73) \\
\end{array}$ \\
\hline Total proteins $(\mathrm{g} / \mathrm{dl})$ & $\begin{array}{l}3.87^{\mathrm{a}} \\
(0.15) \\
\end{array}$ & $\begin{array}{l}4.29^{b} \\
(0.11) \\
\end{array}$ & $\begin{array}{l}4.28^{b} \\
(0.09) \\
\end{array}$ & $\begin{array}{l}4.04^{\mathrm{ab}} \\
(0.10)\end{array}$ \\
\hline Albumin $(\mathrm{g} / \mathrm{dl})$ & $\begin{array}{l}2.24^{\mathrm{a}} \\
(0.02) \\
\end{array}$ & $\begin{array}{l}2.43^{\mathrm{b}} \\
(0.03) \\
\end{array}$ & $\begin{array}{l}2.42^{\mathrm{b}} \\
(0.07) \\
\end{array}$ & $\begin{array}{l}2.31^{\mathrm{ab}} \\
(0.06) \\
\end{array}$ \\
\hline Globulin $(\mathrm{g} / \mathrm{dl})$ & $\begin{array}{c}1.62 \\
(0.17) \\
\end{array}$ & $\begin{array}{c}1.86 \\
(0.10) \\
\end{array}$ & $\begin{array}{c}1.86 \\
(0.05) \\
\end{array}$ & $\begin{array}{c}1.73 \\
(0.15) \\
\end{array}$ \\
\hline $\begin{array}{l}\text { Total Cholesterol } \\
(\mathrm{mg} / \mathrm{dl})\end{array}$ & $\begin{array}{l}116.38^{\mathrm{ab}} \\
(11.55) \\
\end{array}$ & $\begin{array}{c}115.71^{\mathrm{ab}} \\
(3.42)\end{array}$ & $\begin{array}{l}99.24^{\mathrm{b}} \\
(4.13) \\
\end{array}$ & $\begin{array}{c}126.76^{\mathrm{a}} \\
(3.02) \\
\end{array}$ \\
\hline Triglyceride $(\mathrm{mg} / \mathrm{dl})$ & $\begin{array}{l}77.14^{a} \\
(4.37) \\
\end{array}$ & $\begin{array}{l}80.21^{\mathrm{a}} \\
(2.95) \\
\end{array}$ & $\begin{array}{l}86.21^{a} \\
(4.36) \\
\end{array}$ & $\begin{array}{c}100.13^{b} \\
(4.11)\end{array}$ \\
\hline Uric acid $(\mathrm{mg} / \mathrm{dl})$ & $\begin{array}{l}5.61^{a} \\
(0.55) \\
\end{array}$ & $\begin{array}{l}6.49^{a} \\
(0.28) \\
\end{array}$ & $\begin{array}{l}5.88^{a} \\
(0.36) \\
\end{array}$ & $\begin{array}{l}8.29^{\mathrm{b}} \\
(0.79) \\
\end{array}$ \\
\hline Creatinine $(\mathrm{mg} / \mathrm{dl})$ & $\begin{array}{l}0.31^{\mathrm{a}} \\
(0.01)\end{array}$ & $\begin{array}{l}0.30^{\mathrm{a}} \\
(0.00)\end{array}$ & $\begin{array}{l}0.36^{\mathrm{b}} \\
(0.01) \\
\end{array}$ & $\begin{array}{l}0.35^{\mathrm{b}} \\
(0.02)\end{array}$ \\
\hline Calcium (mg/dl) & $\begin{array}{l}9.02^{\mathrm{a}} \\
(0.29) \\
\end{array}$ & $\begin{array}{l}9.66^{\mathrm{ab}} \\
(0.23)\end{array}$ & $\begin{array}{l}9.10^{\mathrm{a}} \\
(0.19)\end{array}$ & $\begin{array}{l}10.13^{\mathrm{b}} \\
(0.32) \\
\end{array}$ \\
\hline Phosphorus (mg/dl) & $\begin{array}{l}4.65^{\mathrm{ac}} \\
(0.20)\end{array}$ & $\begin{array}{l}3.97^{\mathrm{b}} \\
(0.13)\end{array}$ & $\begin{array}{l}4.83^{a c} \\
(0.10)\end{array}$ & $\begin{array}{l}4.22^{c} \\
(0.15) \\
\end{array}$ \\
\hline
\end{tabular}

${ }^{a b c}$ Superscripts in a row indicate significant differences between the groups, $\mathrm{p}<0.05$

\section{Conclusions}

Based on the result of the study, it was concluded that the high and mid doses of the root extract of Anarcaduim occidentale extract caused a significant decrease in serum alanine aminotransferase activity and creatinine level while the mid and low doses increased lymphocyte and monocyte numbers. High and low doses caused a decrease in serum calcium while the mid dose caused a decrease in serum phosphorus level. These significant alterations especially in the serum calcium and phosphorus levels may affect egg lay in birds and should be used in caution during disease treatment in laying birds. 


\section{Authors' Contributions}

Okoye, J.O.A conceived the idea and designed the work with Anaga A.O., Omeke J.N. and Agina O.A. carried out the experiment under the direct supervision of Anaga A.O., Ihedioha J.I., did all the statistical analysis and wrote the manuscript. All authors read and approved the final manuscript.

Ethical approval (for researches involving animals or humans)

The principles governing the humane use and conduct of experiments with animals were strictly observed during this study, and the experimental protocol was approved by the Institutional Animal Care and Use Committee of the Faculty Veterinary Medicine, UNN. (Approval Reference Number: FVM-UNNIACUC-2018-0443).

\section{Acknowledgements}

Authors are grateful to Mr Agbakwulu IO, of the Department of Veterinary Anatomy, Michael Okpara University, Umudike, Imo State, for preparing the histopathological sections

\section{Conflict of Interests}

The authors declare that there are no conflicts of interest related to this article.

\section{References}

Afolabi KD, Akinsoyinu AO, Olajide R, Akinleye SB (2010). Haematological parameters of the Nigerian local grower chickens fed varying dietary levels of palm kernel cake. In: Proceedings of 35th Annual Conference of Nigerian Society for Animal Production, pp 247.

Agedah CE, Bawo DDS, Nyananyo BL (2010). Identification of antimicrobial properties of cashew, Anacardium occidentale L (Family Anacardiacaea). International Journal of Applied Management Sciences 14(3):25-27. https://doi.org/10.4314/jasem.v14i3.61455

Allain CC, Poon LS, Chan CS, Richmond W, Fu PC (1974). Enzymatic determination of total cholesterol. Clinical Chemistry 20:470-475.

Armar-Klemesu M, Maxwell D (1999). Accra: urban agriculture as an asset strategy. In: Baker N, Dubbeling M, Gundel U, Koschella S, de Zeeuw H (Eds). Supplementary Income and Diets. Growing Cities, Growing Food, Havana, Cuba pp 234-236.

Arekemase MO, Oyeyiola GP, Aliyu MB (2011). Antibacterial activity of Anacardium occidentale on enterotoxin producing bacteria. International Journal Biology 3(4):392-399. https://doi.org/10.5539/ijb.v3n4p92

Aroche R, Martinez Y, Ruan Z, Guan G, Waititu S, Nyachoti CM, Mas D, Lan S (2018). Dietary inclusion of a mixed powder of medicinal plant leaves enhances feed efficiency and immune function in broiler chickens. Journal of Chemistry. https://doi.org/10.1155//4073068

Benjamin MM (1981). Outline of veterinary clinical pathology. $3^{\text {rd }}$ Ed. Iowa State University Press, Ames, Iowa, USA.

Blass KG, Theibert RJ, Lam LK (1974). A study of the mechanism of the Jaffe reaction. Journal of Clinical Biochemistry 12:336-343. https://doi.org/10.1515/cclm.1974.12.7.336

Campbell TW (2012). Haematology of birds. In: Thrall MA, Weiser G, Allison R (Eds). Veterinary Haematology and Clinical Chemistry. $2^{\text {nd }}$ Ed. Wiley Ames, Iowa pp 238-276.

Coles EH (1986). Veterinary clinical pathology. $4^{\text {th }}$ Ed. WB Saunders Philadelphia. 
Doumas BT, Biggs HG (1972). Simple method of albumin determination. Clinical Chemistry 7:175.

Drury RAB, Wellington EA (1976). Preparation of tissues for microtomy. In: Carleton's Histological Technique. $4^{\text {th }}$ Ed. New York and Toronto, Oxford University Press New York and Toronto, pp 33-114.

Fawcett JK, Scott JE (1960). A rapid and precise method for the determination of urea. Journal of Clinical Pathology 13:156-59. https://doi.org/10.1136/jcp.13.2.156

Goodwin JF (1970). Quantification of serum inorganic phosphorus, phosphatase and urinary phosphate without preliminary treatment. Clinical Chemistry 16(9):776-780.

Harr KE (2009). Diagnostic value of biochemistry. In: Harrison GJ, Lightfoot TL (Eds). Clinical Avian Medicine. IVS Ithaca New York.

Higgins TE, Beutler E, Doumas BT (2008). Measurement of haemoglobin in blood. In: Burtis CA, AshwoodER. Bruns DE (Eds). Tietz Fundamentals of Clinical Chemistry. $6^{\text {th }}$ Ed. Saunders Elsevier Missouri, pp 514-515.

Ifesan BOT, Fashakin JF, Ebosele F, Oyerinde SA (2013). Antioxidants and antimicrobial properties of selected plant leaves. European Journal of Medicinal Plant 3(3):465-473. https://doi.org/10.9734/EJMP/2013/3383

Igwe AO, Eze DC, Nwakudu ON (2017). Haematological changes in Isa-brown laying chickens (Gallus gallus domesticus) experimentally infected with velogenic Newcastle disease virus. Sokoto Journal of Veterinary Science 15(1):27-35.

Igwe AO, Ihedioha JI, Okoye JOA (2018). Changes in serum calcium and phosphorus levels and their relationship to egg production in laying hens infected with velogenic Newcastle disease virus. Journal of Applied Animal Research 46(1):523-528. https://doi.org/10.1080/09712119.2017.1352506

Isaac LJ, Abah G, Akpan B, Ekaette IU (2013). Haematological properties of different breeds and sexes of rabbits. Proceedings of the 18th Annual Conference of Animal Science Association of Nigeria, pp 24-27.

Jassim SA, Naji MA (2003). Novel antiviral agents: a medicinal plant perspective. Journal of Applied Microbiology 95:412-427. https://doi.org/10.1046/j.1365-2672.2003.02026.x

Kessler GM, Wolfman (1964). O- cresolphthalein direct method for in vivo determination of calcium in serum, plasma and urine. Clinical Chemistry 10:686-704.

Kohn RA, Allen MS (1995). Enrichment of proteolytic activity relative to nitrogen in preparation from the rumen for in vitro studies. Animal Feed Science and Technology 52(1-2):1-14. https://doi.org/10.1016/03778401(94)00711- H

Etim NN, Williams ME, Akpabio U, Offiong EE (2014). Haematological parameters and factors affecting their values. Agricultural Science 2(1):37-47. https://doi.org/10.12735/as.v2i1p37

Nwozo SO, Afolabi AB, Oyinloye BE (2016). Antioxidant, lipid modulating and hypoglycaemic effects of aqueous extract of Anacardium occidentale leaves instreptozotocin-induced diabetic rats. Journal of Molecular Pathophysiology 5(4):59-65. https://doi.org/10.5455/jmp.20160904104639

OECD (2001). Guideline for testing of chemicals. Acute toxicities up and down procedures 425:1-26. www.oecd.org./dataoced/17/51/1948378.pdf

Omeke JN, Anaga AO, Okoye JOA (2018a). Brine shrimp lethality and acute toxicity tests of different hydro methanol extracts of Anacardium occidentale using in vitro and in vivo models: a preliminary study. Comparative Clinical Pathology 27(6):1717-1721. https://doi.org/10.1007/s00580-018-2798-y

Omeke JN, Ezema WS, Eze DC, Okoye JOA (2018b). Lose dose velogenic viscerotropic Newcastle disease virus infection caused 30\% mortality in broiler but none in Lohmann Brown layer chickens. Journal of Applied Animal Research 46(1):1352-1357. https://doi.org/10.1080/09712119.2018.1505620

Omojasola PF, Awe S (2004). The antibacterial activity of the leaf extract Anacardium occidentale and Gossypium hirsutum against some selected microorganisms. Bioscience Research and Communication 60(1):25-58.

Ozer J, Ratweb M, Shawe M, Vanhaelea-Fastre R, Declercq JP, Van Meerssche M (2008). The current state of serum biomarker of hepatotoxicity. Toxicity 245:194-205. https://doi.org/10.1016/j.tox.2007.11.021

Pastore SM, Gomes PC, Rostagno HS, Albino LFT, Calderano AA, Vellasco CR, da Silva Viana G, de Almeida RL (2012). Calcium levels and calcium: available phosphorus ratios in diets for white egg layers from 42 to 58 weeks of age. Revista Brasileira de Zootecnia 41:2424-2432.

Ramaiah SK (2011). Preclinical safety assessment: current gaps, challenges and approaches in identifying translatable biomarkers of drug induced liver damage. Clinics in Laboratory Medicine 31:161-172. https://doi.org/10.1016/j.cll.2010.10.004 
Saulawa LA, Ukachukwu SU, Onwudike OC, Garba MG, Aruwayo A (2012). Effect of quantitative replacement of baobab (Adansonia digitata) seed meal for soya beans mealin broiler finisher diet. ASAN-NIAS Joint Annual Conference, Abuja, Nigeria, pp 525-528.

Schalm OW, Jain NC, Carroll EJ (1975). Veterinary hematology. $3^{\text {rd }}$ Ed. Lea and Febiger, Philadelphia.

Shafe MO, Omolaso BO, Igbokwe VU, Sopuru M, Dare BJ, Olaniyan OT (2014). Anacardium occidentale leaves extract regulate cholesterol and demonstrate anti-diabetic effects on wester rats (Rattus norvegicus). Standard Journal of Plant Sciences 2(3):44-50.

Sirois M (2015). Laboratory procedures for veterinary technicians. $6^{\text {th }}$ Ed. Mosby Inc.

Stockham SL, Scott MA (2008). Fundamentals of veterinary clinical pathology. $2^{\text {nd }}$ Ed. Blackwell Publishing Ames Iowa USA.

Thrall MA, Weiser MG (2002). Haematology. In: Hendrix CM (Ed). Laboratory Procedures for Veterinary Technicians. $4^{\text {th }}$ Ed. Mosby Incorporated Missouri, pp 29-74.

OPEN ACCESS

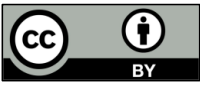

The journal offers free, immediate, and unrestricted access to peer-reviewed research and scholarly work. Users are allowed to read, download, copy, distribute, print, search, or link to the full texts of the articles, or use them for any other lawful purpose, without asking prior permission from the publisher or the author.

License - Articles published in Notulae Scientia Biologicae are Open-Access, distributed under the terms and conditions of the Creative Commons Attribution (CC BY 4.0) License.

(c) Articles by the authors; SHST, Cluj-Napoca, Romania. The journal allows the author(s) to hold the copyright/to retain publishing rights without restriction. 